\title{
THE NARRATIVE CONSTITUTION OF IDENTITY: THE CASE OF PASTORAL AND MINE WORKERS' COMMUNITIES FROM THE REGION OF VALEA JIULUI, ROMANIA
}

\author{
Ana Pascu \\ The National Museum of the Romanian Peasant, Romania \\ e-mail:ana2ania@yahoo.com
}

\begin{abstract}
The start of mine exploitation in Valea Jiului after 1840 has caused the birth of two types of local identity communities: the natives (the Romanian peasants) and the newcomers (the foreign miners) who continue even today to redefine themselves, being closely intertwined. The city dwellers were called 'barabe' by the shepherds, and the shepherds were called 'momârlani' by the city inhabitants. The relations between them were tense from the beginning and have considerably influenced the strategies used in building their constitution of identity. They also reflect in the identity narratives which can be found in Valea Jiului in the present. The analysis of those narratives shows a common history, filled with tension, negation and acceptance.
\end{abstract}

Keywords: constitution of identity, cultural heritage, identity narratives, mine workers, pastoral communities 


\section{The Preliminary Context of the Research. Geographical and Historical Data}

Valea Jiului (currently 120,000 inhabitants) is a geographical hollow situated in the Southern Carpathians. The hollow is surrounded by Şureanu, Parâng, Vâlcan and Retezat mountains. In North, it neighbours Țara Hațegului hollow. There are two main rivers: West Jiu $(51 \mathrm{~km})$ and East Jiu $(28 \mathrm{~km})$, which come together somewhere close to Petroşani city, forming the Jiu river $(348 \mathrm{~km})$.

Valea Jiului belonged to the Dacian state; in $106 \mathrm{a}$. Chr. it was part of the Roman province called Dacia Felix. The discovered coins, dating back to the $4^{\text {th }}$ century a. Chr. prove that the region has been continuously inhabited by a proto-Romanian and, subsequently, a Romanian population. Belonging to Transylvania, it was included in the Hungarian Kingdom from the beginning of the $11^{\text {th }}$ century. It remained in the Austro-Hungarian Empire until 1918, when Transylvania and Romania united.

In the $15^{\text {th }}$ century, the noblemen from Țara Hațegului who owned land in Valea Jiului have sent Romanian serfs to live there, giving them a piece of land and receiving in exchange a part of the annual harvest and animals (Stanca 1996: 41). After the fall of serfage (1848), former serfs bought land from noblemen. However, most of the lands remained under noblemen control who, after discovering coal, sold them to the mining societies.

In 1840, they began exploiting coal. They built the Petroşani - Simeria railway (1867-1870). Petroşani city becomes the center of the mining area (appr. 1890). The population is growing fast: the mining societies attract mine diggers from across the Empire (Slovakians, Germans, Austrians, Croatians, Romanians) and ensure living places for them in colonies and provisions with reduced prices. Around 1900, some economic problems and accidents appear and many mines close down; the population decreases.

The mine diggers' situation improves after 1918, when Transylvania unites with Romania, and then gets worse during the global crisis between 1929 and 1933 and during the Second World War.

During the communist age, the mining industry grew fast. Inhabitants across the country (Oltenia, Moldova, Transylvania, Banat) came or were forced to come and work in mines. The cities developed fast.

After the Revolution in December 1989, the Mineriads from the' 90 affected the image of Valea Jiului at the national level. The mine diggers were summoned 
to Bucharest in 1990 and 1991, 'to defend democracy'; in University Square, there were violent conflicts with the demonstrants. It is not only the mine diggers' image that suffered, but also the image of Valea Jiului, because in the Romanian conscience, Valea Jiului means coal exploitation. As a consequence, they avoid talking about Valea Jiului in mass media.

At the moment, after some national and european political decisions, the mines are closed.

\section{Communities}

The fast-growing population of Valea Jiului after 1840 caused tense relations between the natives and the newcomers. The first generation of newcomers and the local inhabitants greeted each other with disapproval because of their ethnic, cultural and language differences.

The peasants were living in scattered villages in the mountains, where they grew sheep and cows in a traditional manner; the mining societies crowded mine diggers' homes in the valley, in the cities. This spacial polarization favoured from the beginning the formation of some distinct communities. People preferred to live in parallel, avoiding contact, and manifested their disapproval through finding ironic names for the others. The city dwellers were called 'barabe' or 'venituri' ("the ones who came here", actually meaning "who have no roots here, like us") by the shepherds, in contrast with 'oamenii de vatră' (the people who have been living in the village for centuries), and the peasants were called 'momârlani' by the city inhabitants (Gălățan-Jieț 2005: 14).

The local inhabitants were Romanians. 'Barabele' had different ethnic origins, but, as they were always working in mines, dealing with danger, they soon crossed ethnic, linguistic and cultural barriers. Interethnic marriages were frequent and the spirit of religious tolerance has grown. This is why 'barabele' can be considered a homogeneous group, at least in comparison to 'momârlanii', who have stubbornly kept intact their inherited culture, clothing, lifestyle, traditional occupations, even local animal breeds and fruit-bearing trees, up to the present. The repartition of city dwellers in villages and cities has not intertwined either with identity building: 'momârlani' and 'barabe' remain 'momârlani' or 'barabe', no matter which village or city they live in.

In the present, from the approx. 120,000 inhabitants, only $10,000-15,000$ are 'momârlani'. 


\section{Purpose}

Over time, the historical, political, social and economic conditions have caused 'momârlani' and 'barabe' to interact, to share a common history. After generations of separation, 'momârlani' became mine diggers during the communist times (in Romania, the communist regime lasted in from 1945 to 1989), and worked together with 'barabe, which allowed, at individual level, a better understanding of each other; even so, the relations between them remain tense up to this day, even though the reasons have changed.

The interactions between the two groups have fundamentally contributed to the construction of the two identities in Valea Jiului. They reflect in the identity narratives, having a significant position within them. The interest manifested for this domain is the main subject of the conversations with the outsiders, especially the 'momârlan' ones. The identity narratives are known at the same level in all communities, which proves their importance for all inhabitants.

All in all, we are going to analyse the relations between 'momârlani' and 'barabe' starting from the identity narratives which are circulating in Valea Jiului in the present, whose traces can be found also in the reports about Valea Jiului, published in printing press at the beginning of the $20^{\text {th }}$ century.

\section{Theoretical Markers}

Communities define their identity by self-reference and by referencing to the Other; this process is more visible when the cultural differences are bigger, like in Valea Jiului. But P. Ricoeur says that identity built this way is fragile because of many reasons, such as "the confrontation with the Other, felt as a threat. [...] Indeed, the humiliation, the real or imaginary touches brought to self-respect under the poor-tolerated hit of alterity cause the relation between identity and alterity to switch from acceptance to denial or exclusion" (Ricoeur 2001: 103). He adds another cause: the violence of the founding heritage. "The same events, says Ricoeur, might mean glory for some, and humiliation for others" (Ricoeur 2001: 104).

The relations of power between the communities in Valea Jiului have been unequal from the beginning. 'Barabe' had the state's support, while 'momârlani' were under domination and stayed inferior as number, wealth, economic power 
and prestige. It is said that this inferiority has influenced the construction of identity.

The process of construction of identity takes a long time and develops through some talented individuals, capable of turning the events into symbolic narratives and establishing relationships between their meanings (Anastasio et al. 2012: 115), according to the necessities of their own identity project; at the same time, the group will be resistant to changes, if these violate its identity project (Anastasio et al. 2012: 173). The events have multiple meanings and each group accepts a certain one (Anastasio et al. 2012: 107-108), which leads to fights and negociations (Anastasio et al. 2012: 115).

Margaret R. Somers points out that when the identity of a person (or a group) is not freely expressed, but stifled by the narratives of the dominant group, this will be expressed through counter-narratives, that belong to 'excluded voices', that will reveal 'alternative values' because they refer to social realities that are unknown for the privileged (Somers 1994: 631).

The way these identity narratives circulate is also interesting. The conversations when the people remember the past constitute an important medium for the creation of collective memories, claim Coman. But the conversation is not the only factor. Media, texts, public officials, museums, and monuments are just an example of sources that foster consensus (Coman et al. 2009: 139). In Valea Jiului, identity narratives circulate in both ways: orally and through mass media.

\section{Metodology}

The process of forming identities in Valea Jiului lasted for 160 years (and continues today). After the Revolution in 1989, journalists, teachers, sociologists and freelancers with no superior studies have been involved in the promoting history and cultural patrimony, in an effort to rebuild the identity of Valea Jiului, which has been powerfully affected by Mineriads in 1990 and 1991 and by the process of mine closure. Their actions are appreciated by the inhabitants. For instance, Marian Boboc, journalist for Ziarul Văii Jiului (The Journal of Valea Jiului, online: www.zvj.ro), has systematically republished, beginning with 2006, over 30 volumes, reports and memorial articles from the press of the beginning of the $20^{\text {th }}$ century. Florin Mugurel has launched a site where he posts documents, images and memories, especially about mining, but also 
about 'momârlani', with the help of other local collaborators. His purpose is to rebuild the identity of Valea Jiului:

The idea of this site was the desire to leave something behind for the community I belong to [...]. Before starting a few years ago, I searched the web for a site that was as rich in the history of this area as possible: unfortunately, I did not find one and this is how this one was born. Its purpose is to wash the ugly image left by the post-revolutionary Mineriads and show everybody the true face of Valea Jiului and of the people that live here! (Mugurel, http://valeajiului.blogspot.ro/p/despre-noi.html).

Dumitru Gălățan-Jieț, 'momârlan', has published more than ten books about the traditional lifestyle of 'momârlani'. There are also other social actors that look for documents, confessions or old photos; they exhibit objects in small ethnographic 'museums', contributing to the procces of reconstructing the identity of Valea Jiului.

Those locals are to be thanked for facilitating the access to these hard-toreach documentary sources that we have looked into carefully to understand the evolution of relations between communities, as time passed. At the same time, they action as Narrators (Coman et al. 2009: 133): they introduce unshared memories and everyting they publish enters oral circulation.

For this study, I adopted an ethnographic approach and analysed a set of identity narratives collected through interviews realised between 2008 and 2017 in the region of Valea Jiului, in the context of some research projects undergone by the National Museum of the Romanian Peasant. My conclusions were confirmed by participant observation: between 2012 and 2014 I lived in the house of some 'momârlani' during the research and I participated in the most important traditional customs.

\section{In a Conflict from the Beginning}

The analysis of documentary sources proves that the locals suffered at the beginning of the mining exploitation (1840). There was an inevitable ethnic conflict, the inhabitants being Romanians and the newcomers, mostly foreigners. They spoke different languages, and they couldn't understand each other for many decades. Generally speaking, 'momârlanii' did not learn another 
language, not even Hungarian, which was the administration's language until 1918. This attitude was not 'primitive', but a strategy to keep their own identity in an unfavourable climate.

The situation gets more complicated through the economic conflict with the Hungarian authorities: the first mining societies, which belonged to some noblemen, imperial families and were ruled mainly by Hungarian and German engineers, bought some land to exploit from the noblemen, but also from free peasants. As the mines developed, the Hungarian state issued a law which stipulated the expropriation of the necessary lands, in exchange of an insufficient amount of money. The 'momârlani' peasants owned grasslands and forests, just enough to provide the needs of the household. In 1928, a 'momârlan', Pătru Vasilie, interviewed by a journalist anonim ([Anonymous] 2017: 179-195), denounced the abuses: the directors often used to expropriate grasslands from the 'momârlani' in the name of the mine, but they kept it for themselves and sold all the hay back to the peasants.

The religious conflict shows how tense the relation between peasant and mine diggers was. The peasants have been Orthodox for a long time. The pressures coming from the imperial administration in the 18th century and in the beginnning of the 19th century have determined the movement of 'momârlani' from the West Jiu to the Greek-Catholic Church. The communities from the East Jiu have remained Orthodox. From 'barabe', the Romanian mine diggers were mostly Orthodox, and the other ethnic groups had other religions: Catholic, Reformed, Evangelic, Unitarian, etc.

No other cult has had a church for a long time, because the Hungarian state has not supported the building of churches. The mining societies have donated money and the churches were built after 1860 . Then, a religious conflict has emerged, but not between religions, but between 'momârlani' and 'barabe'. 'Momârlanii' were building an Orthodox Church at Petroșani between 1876 and 1900. The mine diggers came to help and the 'momârlani' denied it violently. At Lupeni, the same thing happened when the Greek-Catholic Church was built (Brânzeu 2017: 69-95).

After 1918, under Romanian administration, the number of 'momârlani' working in the mine grew. In 1927, 'momârlanii' were working in the mining societies, but for auxiliary works. In the summer, they were leaving the mine to work in household. (Hossu-Longin in Boboc 2017b: 62) 
Around the Second World War, 'momârlani' also became mine diggers. In Uricani city, the mine was closed in 1947. Alexandru Zăpadă, a 'momârlan', was called to work as a mine digger - he had experience from the Lupeni mine. He became a symbol for many people from Uricani: the first 'momârlan' mine digger. This symbol marks the change in the mentality of 'momârlani': after this date, 'momârlanii' will try to have at least one mine digger in the family for a safe earning, while the rest of the family continues to raise cattle.

\section{Current Situation}

In 'life story'-type and in structured interviews, the respondents say that 'momârlani' and 'barabe' continued to keep a tense relation during the communist period, even though the political, social and economic conditions have changed.

The hierarchical relations between the two communities have stayed the same, because between 1970 and 1980, the coal exploitation from Valea Jiului has become the most important component of the National Energy Program. This involved favouring the mine workers. At the same time, the communists continued to expropriate the lands of 'momârlani', opening new mines. 'Momârlanii' were moved in blocks of flats. Some of them did not accept apartments in blocks and built/moved their houses on the property, outside the expropriated area.

In order to benefit from the economical advantages, the young 'momârlani' found work as mine diggers, working in mines in the same groups with 'barabele': the communist authorities had a policy of leveraging the differences between groups. This policy diminished a lot the old conflicts, but without eliminating them completely. A 'momârlan' told me that, in his childhood in 1970, at school, other pupils were laughing at him because he was a 'momârlan' and 'had milk in his pockets' (I. D., 'momârlan', interview from 2014). But 'momârlanii' continued to raise animals, for their own household needs and for selling.

After the Revolution, some of the 'momârlani' (the ones who were 50-60 years old in 1989) have recovered their lands and went back in their old homes. Although fully aware that there were underground galleries and danger of collapse, they wanted to move on with their lives on their lands. Still, many of their 
children lived in blocks and adapted to the urban lifestyle. Getting further from the traditional lifestyle, they married 'barabe', Romanian or Hungarian, which their parents dissaproved of, because of both identity and practical reasons: whoever was to be married into a 'momârlan' family had to integrate in their traditional lifestyle.

In the present, the mine closure forced the young generations, especially the 'barabe' but also 'momârlani', to abandon their traditional lifestyle, looking for work in cities or abroad.

In the last few years, 'momârlani' have grown just a few animals, for the needs of their household alone, because the mine closure reduced the power of purchase and they cannot sell their products anymore. They believe that the mine, even though it helped them prospere, has also brought a lot of damage, offering a way to earn money more easily than growing animals.

'Momârlanii' are sheperds from father to son. But I earn money easier out of mining. Why should I stay on the top of the hill with a bat and watch over sheep, when I can go, work for 8 hours and then sleep? It has broken us; it has cause this rupture between us (V. C., 'momârlan', interview from 2014).

The 'Momârlani' of the over 50-years-old generation (also younger people) are trying to build a new identity for Valea Jiului by promoting their traditional customs. Dance crews were formed to promote their traditional music and dance. Lately, the city halls took over the 'momârlani' customs, promoting them for the City Days. But the city dwellers don't feel represented by the 'momârlani' customs and the people's discontent can restore the past conflicts. The 'momârlani' do not approve of this either, because they would rather organise their holidays by themselves.

\section{The Analysis of Identity Narratives}

In Valea Jiului, the most identity narratives try to explain the two names, of 'momârlan' and 'barabă'. The origin of those words is uncertain; this allowed the inhabitants to make different assumptions, using all the available documentary sources. Neither the genuineness of the explanation nor its credibility, but the existence of these narratives themselves is significant. And the fact that most of 
them claim that the two names were invented by the other community proves how strong the mutual influence on the identity construction was.

Not even in 1926 did they know where they come from. A Greek-Catholic priest, N. Brânzeu, said that 'barabă' doesn't come from the Bible version of Baraba, but probably from 'Bauarbeiter', 'building worker' (Brânzeu 2017: 73-74). In 1937, it was believed that 'momârlani' comes from the Hungarian word 'maradváy' (sic!), meaning 'rămăşiță, in the sense of 'natives, traces of the Dacian people' or by referring to their 'poor condition of people who live alone in the mountains' (Vintilescu 1937: 505). These representations circulate today in the identity narratives. There's a tendency to create counter-narratives to satisfy self-esteem: discontent of being considered 'traces', 'momârlanii' consider themselves 'descendants of Dacians'. Because the transformation from 'maradványi' to 'momârlani' is not credible, they imagined that the natives heard the men calling them like that and adopted the word, adapting it to Romanian.

More recent dictionaries do not contain these meanings anymore; neither 'momârlanii', nor their names are known at national level and they dislike it. This is why the following representative anecdote has circulated among momârlani:

There was a 'momârlan' who went to Bucharest with some sheep cheese. Another one was screaming:

- Come and have some Sibiu ${ }^{1}$ cheese! Come and have some Sibiu cheese!

Another was screaming something else and so on. So our man thought: 'I have to scream too and sell my cheese.' And he starts:

- Come and have some 'momârlan' cheese!

An old man, very well dressed, comes to him and says:

- Dear man, no offense, I've been everywhere around the world but I have never heard about 'momârlan'. What animal is this? he says, I've never heard about this animal! (P. G., 'momârlan', interview from 2008).

It is believed that the locals called the foreigners 'baraberi' from 'Bahnarbeiter': 'worker at the railway'. Or: 'barabă' comes from the name of Walter Barabek, an engineer of Silesian origins, who designed and built the railway.

It is also believed that the name was given to them by the Italians who came here to work, because they resemble the inhabitants of Marmolada (a mountain region from Italy). In 1937, the 'momârlan' Petru Cic from the Maleia village has told priest Păun Marcu Jura that the Italian woodworkers he was working 
with have called the inhabitants 'marmolani'. The other miners borrowed the word and it was adapted in Romanian through metathesis (Gălățan-Jieț 2017).

In the same article, D. Gălățan-Jieț says that the name 'barabe' wasn't given to the miners by 'momârlani', but it was brought to Valea Jiului by the 'moți' from the Western Romanian Carpathians. When they were leaving for work in the country, they would say that they go in 'bărăbie', so they called themselves 'barabe. The name would later be used by 'momârlani' for all newcomers.

Another respondent told me that the term 'barabă' meaning 'mine worker' also circulates in Năsăud, another mining region of the country. It may be that the term 'barabă' from Valea Jiului and the one from Năsăud have a common origin, because in the mining areas there used to come workers from all around the Austro-Hugarian Empire. This would mean that it was not the 'momârlani' who called the miners 'barabe'. The more significant is the fact that the 'momârlani' are atributed the paternity of this denomination.

Another series of identity narratives concerns the cultural differences between 'momârlani' and 'barabe. They mutually accuse each other that they do not know and do not appreciate their own culture. The narratives of the dominant group ('barabele') reflect hierarchical relations that have not changed too much. In the present, 'barabele' believe that 'momârlani' are primitive, just like in the past, when they considered them 'unadaptable to what they were bringing - an important industry' (P. U., 'barabă, interview from 2017). Today, miners consider them 'primitive' because they do not enjoy free time and they do no travel, being busy with rising animals:

I had some work colleagues, 'momârlani', they never went out once in their lives, they would spend their holidays sew in hand, at the mountain lodge, where they were raising cattle. One time, one of them went to the seaside and exclaimed: "Oh, mother, what a waterhole!" (G. N., 'barabă, interview from 2017).

'Barabele' accuse 'momârlani' that they do not appreciate the urban culture:

The Local Council (of Petrila) is dominated by them ['momârlani'] [...] Meaning that even though 'barabele' have given the cultural values, 'momârlanii' are the ones who control and decide for the respective values. And they are very opaque, culturally speaking! (I. B., 'barabă, interview from 2017). 
'Barabele' reject the traditional way of thinking, which relies on the inherited value:

But they ['momârlanii'] are constrained by the same thinking: 'If my ol'man did it like this, I'll do it in the same way!' (G. N., 'barabă, interview from 2017).

'Momârlanii' fought back, creating counter-narratives that suggest how complex their traditional culture is. For instance, a 'barabă' does not understand the 'language' of the 'momârlan's' hat:

Do you know how a 'momârlan' wears his hat? If he is tired, he wears it on the back of his head, like this. Usually, when he is happy, he keeps it on one side. And when he is upset, he wears is in the front, like this, so everybody can see that something is wrong (Ionel A., 'barabă, interview from 2014).

In the present, although the tension between the two communities has diminished, it can reappear in case of conflicts. In 2015, I participated at 'nedeia' from the Jieț village. Nedeia is a traditional custom of 'momârlani', which became an identity mark: an alm for the dead, with food, music and specific popular dances. At nedeie, 'barabe' also take part. I noticed that 'momârlani' and 'barabe' dress differently. 'Momârlani' come dressed in traditional clothing, or at least have a piece of popular clothing: the women - a 'ciupeag' (traditional blouse) or a home-hatched bag; the men: specific hats. Barabe are dressed in casual clothes. The local clothing is an identity mark and 'momârlani' consider that people who dress traditionally love the 'momârlan' culture.

But at that event I was warned not to use the word 'momârlan', because the locals get upset, seeing it as a mockery.

\section{Conclusions}

Identity narratives that circulate in Valea Jiului in the present reflect the attempts of some local social actors to change the perception about the communitites of 'momârlani' and 'barabe'; in some cases, their polarisation may be tracked down in narratives and counter-narratives which reflect the hierarchical relations between 'momârlani' and 'barabe' and the attempt of 'momârlani' to reach out 
from their shadowy corner where they have been pushed since the beginning of mining. The actual context, where the mine workers lost a lot of their economic importance because of the mine closure, looks like a favourable moment for 'momârlani', who wish to be known for their traditional culture and who have managed to turn a nickname into an identity name, into a 'name of pride'.

\section{Notes}

1 Sibiu is a well-known region of Romania.

\section{References}

Anastasio, Thomas J. \& Ehrenberger, Kristen Ann \& Watson, Patrick \& Zhang, Wenyi 2012. Individual and Collective Memory Consolidation: Analogous Processes on Different Levels. Cambridge, Massachusetts, London, England: The M.I.T. Press. [Anonymous] 2017. De vorbă cu un țăran de pe Valea Jiului. [Talking to a Peasant from Valea Jiului]. In: Marian Boboc (ed.) Valea Jiului all-inclusive. O bibliotecă într-o carte, întocmită de Marian Boboc [Valea Jiului All-Inclusive. A Library in a Book, Written by Marian Boboc], Vol. 1. Craiova: MJM, pp. 179-195.

Brânzeu, Nicolae 2017. Povestea Văii Jiului de dr. Nicolae Brânzeu, prepozit capitular. [The Story of Valea Jiului by Dr. Nicolae Brânzeu, Capitulary Cleric]. In: Marian Boboc (ed.) Valea Jiului all-inclusive. O bibliotecă într-o carte, întocmită de Marian Boboc [Valea Jiului All-Inclusive. A Library in a Book, Written by Marian Boboc], Vol. 1. Craiova: MJM, pp. 69-95.

Coman, Alin \& Brown, Adam D. \& Koppel, Jonathan \& Hirst, William 2009. Collective Memory from a Psychological Perspective. International Journal of Politics, Culture and Society, Vol. 22 (2), pp. 125-141. DOI: 10.1007/s10767-009-9057-9.

Gălățan-Jieț, Dumitru 2005. Tradiții și obiceiuri în satele din estul Văii Jiului [Traditions and Customs in the Villages from the Eastern Part of Valea Jiului]. Petroşani: Focus.

Gălățan-Jieț, Dumitru 2017. Contribuții la elucidarea termenului de 'barabă’ şi 'momârlan'. [Contributions to Finding the Meaning of the terms 'Barabă' and 'Momârlan']. Avântul Liber [The Free Momentum]. Available at https://www. avantulliber.ro/2017/03/24/contributii-la-elucidarea-termenului-de-baraba-simomarlan, last accessed on 24.08.2018. 
Hossu-Longin, Pompeiu 2017. Valea Jiului din Ardeal [Valea Jiului from Ardeal]. In: Marian Boboc (ed.) Valea Jiului all-inclusive. O bibliotecă într-o carte, întocmită de Marian Boboc [Valea Jiului All-Inclusive. A library in a Book, Written by Marian Boboc], Vol. 2. Craiova: MJM, pp. 49-70.

Mugurel, Florin, Despre noi [About Us]. Available at http://valeajiului.blogspot.ro/p/ despre-noi.html, last accessed on 25.08.2018.

Ricoeur, Paul 2001. Memoria, uitarea, uitarea [Memory, History, Forgetting]. Timișoara: Amarcord. [Ricoeur, Paul 2000. La mémoire, l'histoire, l'oubli. Paris: Seuil.]

Somers, Margaret R. 1994. The narrative constitution of identity: A relational and network approach. Theory \& Society 23, pp. 605-649.

Stanca, Sebastian 1996. Monografia istorico-geografică a localității Petroşeni din Valea Jiului [The Historical-Geographical Monography of Petroșeni from Valea Jiului]. Petroșani: Publishing house Fundația Culturală [Cultural Foundation] Ion D. Sârbu.

Vintilescu, Ion 1937. Merişor, un sat de 'momârlani' de pe pragul porții sud-estice a Țării Hațegului [Merişor, a Village of 'Momârlani' from the South-Eastern Gate of Țara Hațegului (the Country of Hațeg)]. Romanian Sociology, year II, No. 11-12, November-December, pp. 502-507. 